\title{
Poultry Farmers Perceived Constraints and Unwholesome Practices among Feed Mill Industries in Ibadan Metropolis
}

\section{Eniola.O}

Federal College of Forestry, P.M.B. 5087, Jericho, Ibadan

\begin{abstract}
In order to investigate poultry farmers perceived constraints and unwholesome practices among commercial feed mill industries in Ibadan metropolis. Purposive sampling procedure was used for this study and a total of ninety six questionnaires were administered to the farmers out of the one hundred and sixty registered poultry farmers with Oyo State Agricultural Development Project (OSADEP) in Ibadan metropolis.

The socio-economic characteristics of the respondents such as age, marital status, educational level, gender, years of experience, religion were assessed using descriptive statistics, frequency and percentage, while farmer's perceptions on unwholesome practices and types of feed ingredients used and sources were measured using chi-square analytical tool. Other questions like benefits derived and constraints facing self milling in poultry industries were measured using Pearson product method of correlation (PPMC). From the findings it was revealed that majority of the farmers were facing one challenges or the otheras a result of some sharp practices by the so called feed mill industries in Ibadan ranging from poor quality offeeds sold to farmers, short changing the customers in terms of measurement, scarcity of feed ingredients, seasonal instability in agricultural grains among others. Also, (61.5\%) of the farmers agreed that already spoilt feed ingredients can easily be detected since they are not usually bought in large quantities which is one the benefits farme rs derived from self milling.
\end{abstract}

Keywords-Poultry Farmers, Perceived constraints, feed mill, unwholesome practices.

\section{INTRODUCTION}

Poultry industries over time have made tremendous adjustments to meet the increasing demand for inexpensive animal protein and safe supply of meat and eggs. Over three decades, the poultry sector has been growing at more than 5 percent per annum (compared to 3 percent for pig meat and 1.5 percent for bovine meat) and its share in world meat production increased from 15 percent three decades ago to 30 percent currently (FAO, 2006).

Livestock production constitutes an important component of the agricultural economy in developing countries and it is an instrument to socio-economic change, improved income and quality of rural life in Nigeria (Okumadewa,1999). It is an important source of protein presently producing about $36.5 \%$ of total intake of Nigerians. In livestock production, poultry occupies a prominent position in providing animal protein as it accounts for $25 \%$ of local meat production in Nigeria (Okunlola and Olofinsawe, 2007).

In Nigeria, commercial feed milling commenced in 1963 by Pfizer, (Now Livestock feedPlc.). The number of feed mills in the country has been increasing since then. The number of feed millers grew to 303 as at 1983 with a combined installed capacity of 1039 tonnes per hour. Feed production rose from 640,000 tonnes in 1980 to 2.4 million tonnes in 1985, this then declined to about 1.0 million tonnes by 2008 (Eruvbetine, 2009).

An efficient feed mill industry is therefore crucial to the sustainability of viable livestock and poultry production enterprises. The poultry feed industry (broiler and layer industry) according to Fagbenro and Adebayo (2005), dominates the animal feed industry, and accounted for approximately two-thirds (68.2 percent) of the national feed production while the remaining $31.8 \%$ is for livestock such as pig, rabbits and fish. The industry comprises two sectors: the small-scale and the commercial sectors. The commercial 
sector manufactured nearly 1.7 million tonnes or 65.4 percent of the country's poultry feed - this included feeds offered to chickens, guinea fowls, ducks, geese and turkeys (Fagbenro and Adebayo, 2005). The Toll millers and farm mixed feed constitute the remaining $35 \%$ of the total poultry feed produced in the country. The ingredient composition used in poultry feeds is derived using least cost formulation techniques.

Livestock feed industries or mills are found all over the country, with the largest concentration in the south-west zone of the country. These range from small, medium to large scale operators. Currently there are only six (6) well established reputable feedmilling companies in Nigeria. The major commercial feed millers include, Top feeds, Vital feeds, Livestock feeds, Boar feeds, Animal care, Amobyng, and Feed Masters producing more than 50\% of feed requirement of the country while the remaining is balanced by the medium, small scale, toll millers and on farm/ selfmixed feed that can be found all over the country (Bello, 2008). According to Oyediji (2006), increase in demand for feed has led to the emergence of additional feed mills whose size and nature of business differentiate them from one another. According to Munkailaet al., (2012), there exist large scale commercial feed mills whose hourly output ranges from 5tonnes and above, medium scale mills with an output range of 2-4 tonnes and the small scale with an hourly output of 0.5 to 2 tonnes per hour.

\section{METHODOLOGY}

This study involved all registered poultry farmers under Oyo State Agricultural Development Project (OSADEP) in Ibadan Metropolis and a purposive sampling procedure was used for the study, Out of about one hundred and sixty registered poultry farmers in Ibadan Metropolis, ninety sixof them were randomly selected for questionnaire administration.Data was collected using primary source of data obtained from selected registered poultry farmers in Ibadan Metropolis

A well-structured questionnaire was used to collect primary data in Ibadan metropolis while secondary data was obtained from research report, literature and other publications.

\section{RESULTS}

Table1.Socio-Economic Characteristics of the Respondents in the Study Area

\begin{tabular}{|c|c|c|}
\hline Variable & Frequency & Percentage $(\%)$ \\
\hline Sex & & \\
\hline Male & 62 & 64.6 \\
\hline Female & 34 & 35.4 \\
\hline Total & 96 & 100 \\
\hline Age & & \\
\hline $21-30$ years & 23 & 24.0 \\
\hline $31-40$ years & 22 & 22.9 \\
\hline $41-50$ years & 37 & 38.5 \\
\hline Above 50 years & 14 & 14.6 \\
\hline Total & 96 & 100 \\
\hline Religion & & \\
\hline Christianity & 55 & 57.3 \\
\hline Is lam & 36 & 37.5 \\
\hline Traditional & 5 & 5.2 \\
\hline Total & 96 & 100 \\
\hline Marital status & & \\
\hline Single & 9 & 9.4 \\
\hline Married & 74 & 77.1 \\
\hline Divorced & 6 & 6.3 \\
\hline Widow & 7 & 7.3 \\
\hline Total & 96 & 100 \\
\hline Level of education & & \\
\hline No formal education & 13 & 13.5 \\
\hline
\end{tabular}


Adult education

Primary education

Secondary education

Tertiary education

Total
32

32

3

16

96
33.3

33.3

3.1

16.7

100

The result shows that $64.6 \%$ were male and $35.4 \%$ were females and $24 \%$ of the respondents were between the age of $21-30$ years, $22.9 \%$ between the ages of $31-40$ years, $38.5 \%$ between the age of $41-50$ years and $14.6 \%$ are above 50 years of age which shows that majority of the respondents were within the productive year. This also means that respondents involved in poultry farming are at their active age when strength as well as energy to work is readily availablethat is the younger the farmers, the more productive they are (Gingraset al., 2008). Furthermore, about26.1\% of the respondents have within 501-1000 stocks of birds which make it the highest and majority of the respondents realizes between \#50,000-100,000 per year 32.3\% and majority of the farmer's mills between $201-300 \mathrm{~kg}$ of feeds per month $37.5 \%$ that is most of the farmers sampled makes use of feed mills on a regular basis.

Table 2: Farmers Perception on unwholesome practices among feed mill industries

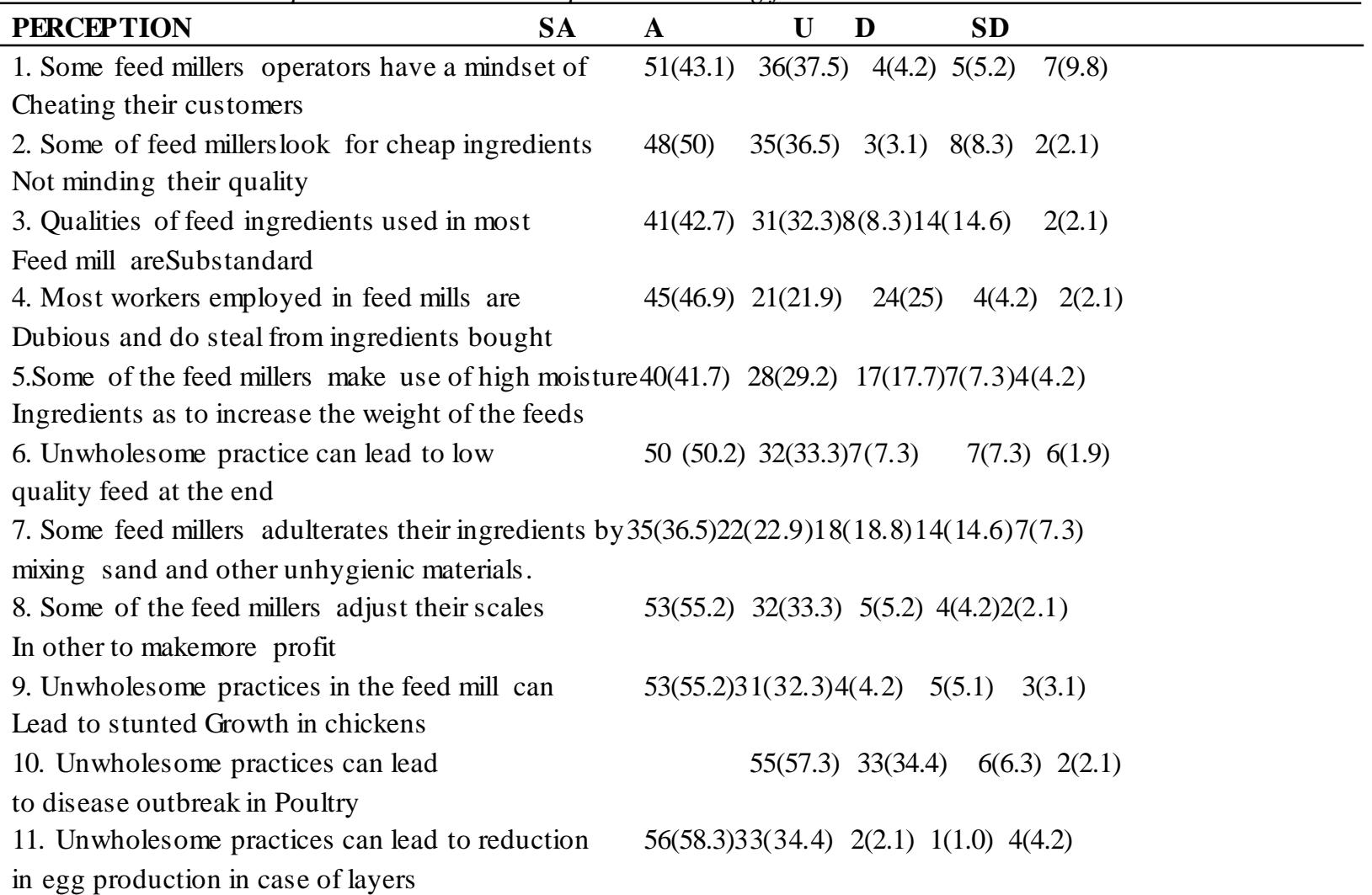

Source: Field survey, 2017

From the above table (53\%) of the respondents strongly believed that unwholesome practices can lead to egg reductions, also, $57.3 \%$ of the farmers strongly agree that unwholesome practices can lead to disease outbreak in poultry. Furthermore, $55.2 \%$ of farmers also believed that some of the feed millers adjust their scale in other to make more profits and that practice alone can lead to lead stunted growths in chickens. $53.1 \%$ of the respondents had strong indications that some of the feed miller operators have a mindset of cutting corners and cheating their customers, also, 52.1\% of respondents also strongly agreed that unwholesome practices can lead to low quality chickens and $50.0 \%$ of the farmers strongly agree that some feed millers look for cheap ingredients not minding their qualities. 
Table 3: Availability of materials for commercial feedmill industry materials

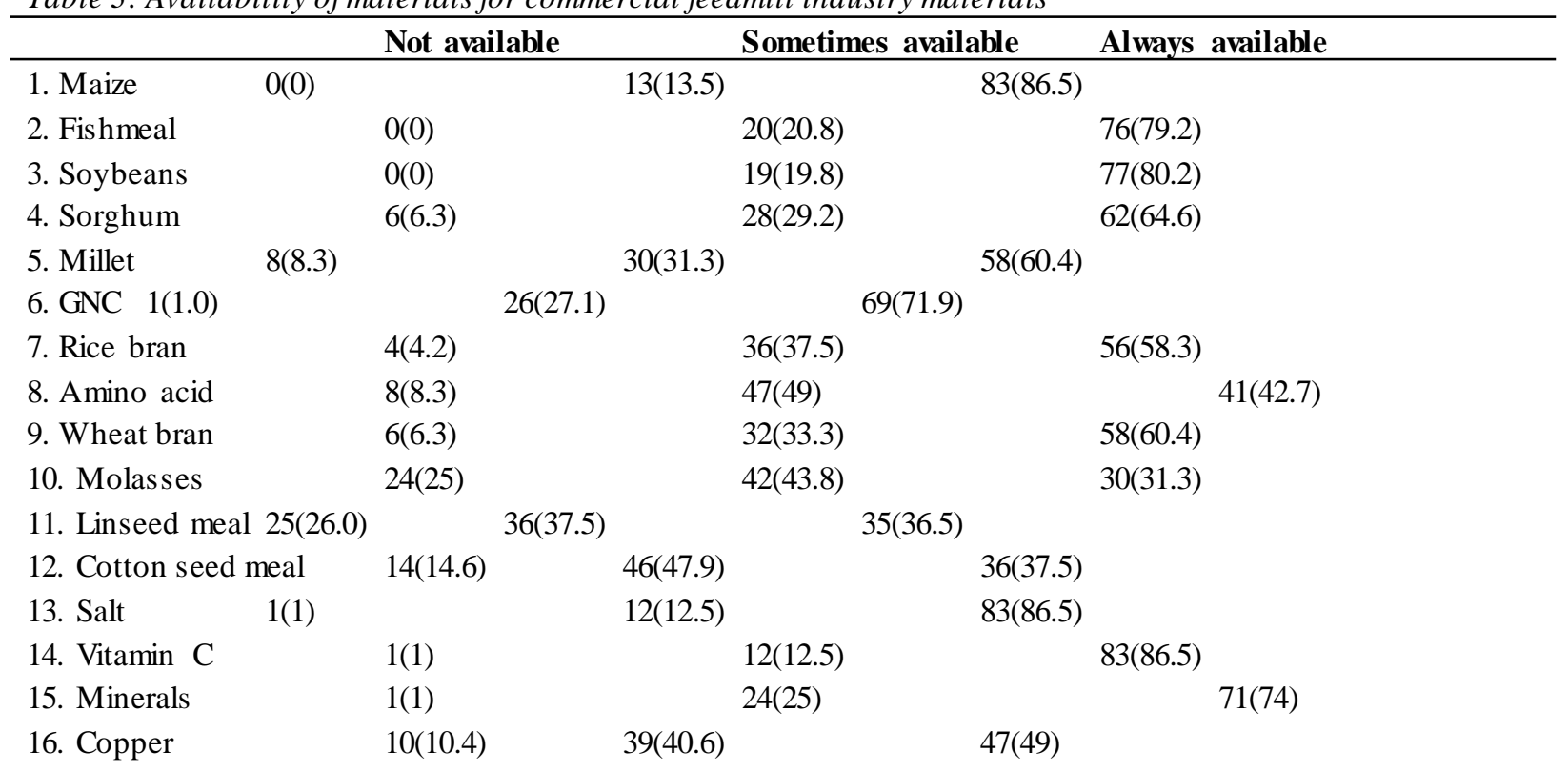

Table 3 continuation: Availability of materials for commercial feedmill industry materials

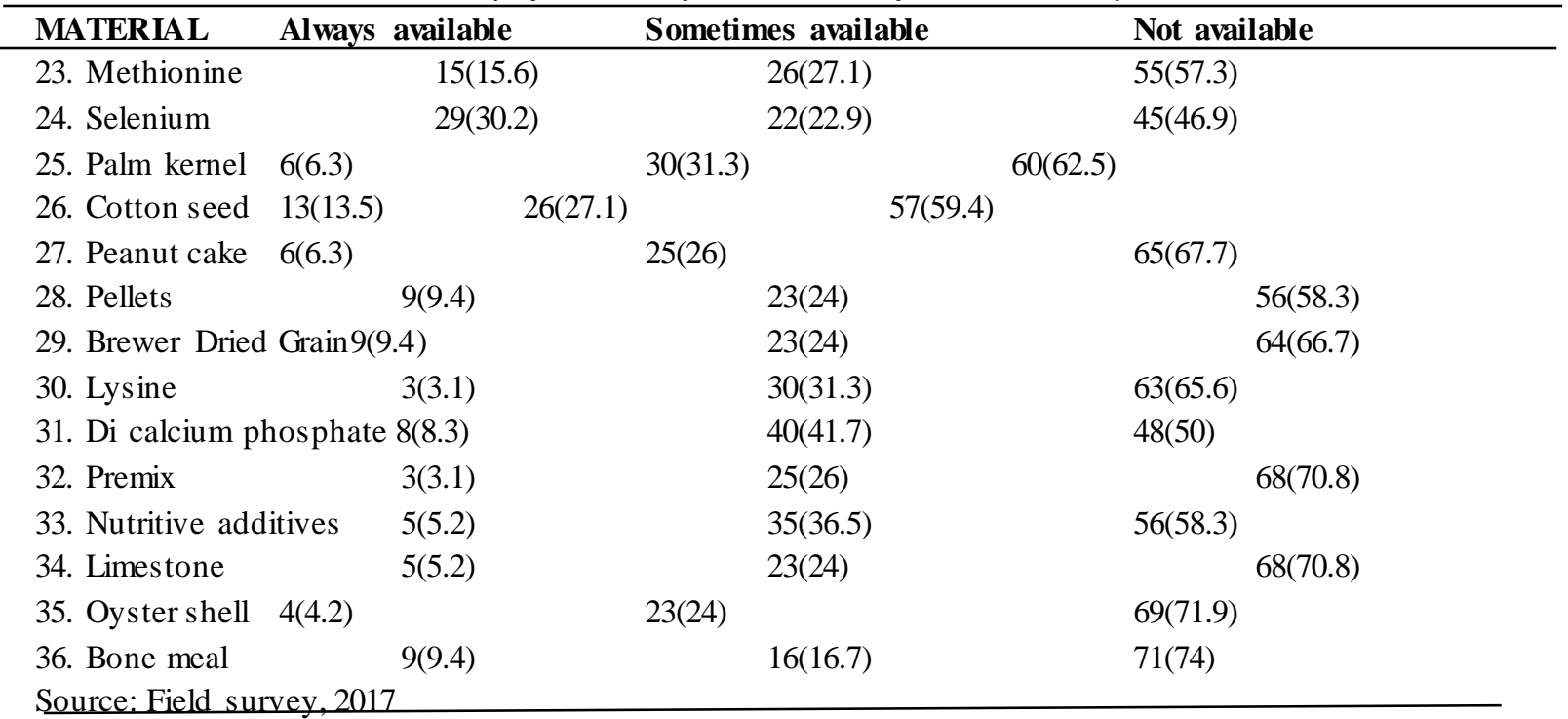

From the table above, Availability of maize as one of the sources of feed ingredients in feed mill industries had $86.5 \%$ which supports Iken and Amusa, 2004, that says 'maize has now risen to a commercial crop on which many Agro-based industries depends on it as raw materials for production. According to IITA 2001, 'maize is highly yielding, easy to process, readily digested and cost less than other cereals. $86.5 \%$ of the respondents also said that salt and vitamin $\mathrm{C}$ is always available, $80.2 \%$ also said that soybeans is always available, $79.2 \%$ of respondents supported that fishmeal is always available,77.1\% of farmers also said that palm-oil is always available, $74.0 \%$ of respondents also agreed that minerals and bone meal materials is always available. 
Table 4: Sources of feed in feed mill industry

\begin{tabular}{llrll}
\hline Sources & Regularly & \multicolumn{1}{l}{ Occasionally } & Never \\
\hline 1. Open markets & $79(82.3)$ & $17(17.7)$ & $0(0)$ & \\
2. Directly from farmers & $44(45.8)$ & $44(45.8)$ & $8(8.3)$ & \\
3. Friends and family & $17(17.7)$ & $46(47.9)$ & $33(34.4)$ \\
4. Industrial waste & $36(37.5)$ & $45(46.9)$ & $15(15.6)$ \\
5. House hold waste & $28(29.2)$ & $43(44.8)$ & $24(25.0)$ \\
6. Extension agent & $20(20.8)$ & $56(58.3)$ & $20(20.8)$ \\
7. Feed mill industries & $67(69.8)$ & $25(26.0)$ & $4(4.2)$ \\
8. Personal farm & $50(52.1)$ & $36(37.5)$ & 10(10.4) \\
\hline
\end{tabular}

Source; Field survey, 2017

Majority (82.3\%) of the farmers regularly get their ingredients from open markets. Close to half $(45.8 \%)$ of the respondents get their own directly from farmers regularly and occasionally.

Also, $47.9 \%$ of respondents occasionally get their ingredients from friends and family who own one farm or the other, $46.9 \%$ of the respondents occasionally get their ingredients from industrial waste. Furthermore, $44.8 \%$ occasionally get the ir ingredients from household waste, $58.3 \%$ occasionally source theirs from extension agents.

Table 5: Benefits derived from self milling

\begin{tabular}{|c|c|c|c|}
\hline Benefits & $\mathbf{L B}$ & MB & \\
\hline more nutritive than conventional feeds $16(16.7)$ & $7(7.3)$ & $18(18.8)$ & $55(57.3)$ \\
\hline 2.Self- milled feed saves a lot of money on the & $12(12.5)$ & $6(6.3)$ & $25(26) 53(55.2)$ \\
\hline
\end{tabular}

Overall cost of production

3.The nutrient content of the feed is retained 15(15.6)9(9.4) $\quad 19(19.8) 53(55.2)$

Through self-mill

4.It is not time consuming $\quad 6(6.3) \quad 16(16.7) \quad 27(28.1) \quad 47(49)$

5.Feeds are prepared in right proportions needed $\quad 7(7.3) \quad 12(12.5) \quad 26(27.1) \quad 51(53.1)$

By the available birds

6.It is usually milled when needed per time $12(12.5) \quad 13(13.5) \quad 25(26) \quad 46(47.9)$

7.Preventive measures are usually taken $\quad 7(7.3) \quad 14(14.6) 22(22.9) 53(55.2)$

8.There is reduced risk attached to self-milling $\quad 7(7.3) \quad 18(18.8) \quad 21(21.9) \quad 50(52.1)$

Compared to commercial feed millers

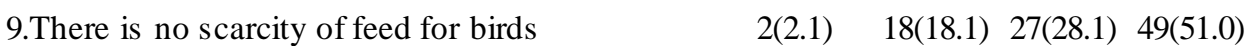

10.Alreadyspoilt feed ingredients are easily $2(2.1) 13(13.5) \quad 22(22.9) \quad 59(61.5)$

Detected

11.Farmers can be sure of the nutritive values $\quad 6(6.3) \quad$ 15(15.6) 21(21.9) 54(56.3)

Quality of the feed at the end

Source: Field survey, 2017

The table above shows the benefits derived by farmers in self-milling. Majorly, (57.3\%) of the respondents agreed to the fact that it is usually more nutritive than that of feed mill industries, also, 55.2\% of respondents agree that self-milling saves a lot of money on the overall cost of production and the nutrient content of the feed is retained through self-milling, $61.5 \%$ of the respondents supported that already spoilt feed ingredients can't be used when doing self-milling. Furthermore, 56.3\% agreed that farmers can be sure of the nutritive values of the ingredients to be used. 54.2\% of the respondents agreed that in self-milling, contamination by rodents and other micro-organis $m$ is reduced in self-milling. 
Table 5: Contraints FacingFarmers in Commercial Feed Mill Industry.

\begin{tabular}{|c|c|c|c|c|}
\hline \multicolumn{2}{|c|}{ Constraints } & \multirow{2}{*}{$\begin{array}{l}\text { N.C } \\
16(16.7)\end{array}$} & Min. C. & Maj.C. \\
\hline 1. & $\begin{array}{l}\text { The feeds are not always in the } \\
\text { Right proportion }\end{array}$ & & $37(38.5)$ & $43(44.8)$ \\
\hline 2. & It is time consuming & $4(14.6)$ & $42(43.8) \quad 40(41.7)$ & \\
\hline 3. & $\begin{array}{l}\text { Contaminated feeds can lead to } \\
\text { Health hazard }\end{array}$ & $8(8.3)$ & $11(11.5)$ & $77(80.2)$ \\
\hline 4. & $\begin{array}{l}\text { Small scale farmers are not usually } \\
\text { Attended to on time }\end{array}$ & $9(9.4)$ & $38(39.6)$ & $49(51)$ \\
\hline 5. & $\begin{array}{l}\text { Feeds meant for one animal can be } \\
\text { Mistaken for another }\end{array}$ & $17(17.7)$ & $39(40.6)$ & $40(41.7)$ \\
\hline 6. & $\begin{array}{l}\text { Epileptics supply of light can lead } \\
\text { to feed scarcity }\end{array}$ & $13(16.3)$ & $35(41.8)$ & $48(41.9)$ \\
\hline 7. & $\begin{array}{l}\text { Shortage of feed ingredients will } \\
\text { lead to unavailability of feeds }\end{array}$ & $6(6.3)$ & $30(31.3)$ & \\
\hline 8. & $\begin{array}{l}\text { Increase in prices of feed materials } \\
\text { Often leads to increase in feed price }\end{array}$ & $5(5.2)$ & $22(22.9)$ & 69(71.9) \\
\hline 9. & $\begin{array}{l}\text { Feeds bought from feed millers are } 5(5 \\
\text { Often lesser thanacclaimed quantity }\end{array}$ & $5.2)$ & $41(42.7)$ & $50(52.1)$ \\
\hline & $\begin{array}{l}\text { Seasonal instability in agricultural5(5. } \\
\text { Crops do affect ingredients }\end{array}$ & & $26(27.1)$ & $(67.7)$ \\
\hline & $\begin{array}{l}\text { Instability in Government policies do } \\
\text { Affect certain crops }\end{array}$ & $12(12.5)$ & $25(26)$ & $59(61.5)$ \\
\hline
\end{tabular}

The above table shows the constraints facing the farmers in feed mill industries. One of the major constraints facing the farmers is the way animals fed such adulterated ingredients are susceptible to diseases attacks $80.2 \%$ of the respondents affirmed this, also feed price increases $71.9 \%$ indiscriminately. Other challenges' facing the farmers ranges from inadequate power supply to instability in Government policies $65.6 \%$ and $67.7 \%$ respectively. In addition there are other constraints like unavailability of feed ingredients and shortage in feed supply due to one reas on or the other.

\section{REFERENCES}

[1] Bello, B. (2008). Feed Crisis: Way out. A Paper Presented at the World Poultry Science Association, Nigeria Branch Seminar, Lagos. March 14-16.

[2] Eruvbetine D. (2009): Revolutionising the Feed Industry for Increased Poultry Production, University of Agriculture, Abeokuta, Nigeria.UNAAB Inaugural Lecture Series No. 26

[3] Fagbenro, O.A. and Adebayo, O.T. (2005):A Synthesis of the Formulated Animal And Aqua feed Industry In SubSaharan Africa: A review of the animal and aquafeed industries in Nigeria. CIFA Occasional Paper No. 26 FAO
Rome.http://www.fao.org/docrep/008/a0042e/a0042e05.htm 22nd March, 2013.

[4] Food and Agricultural Organisation (2006): World agriculture: towards 2030/2050 interim report. Rome.

[5] Gingras, Y., Larviere, V., Maceluso, B. and Robalite, J.P. (2008): the effect of ageing on reseachers, publication and citation patterns. Vol,iii, pg 12.

[6] Iken, J.E., \&Amusa, N.A. (2004): Maize research and production in Nigeria, African journalof biotechnology 3(6); 302-307.

[7] Munkaila, A. A; Taiwo, A. G. and Adeeko A. L (2013): Economic Analysis of Feedmill Industries in Ogun and Oyo States, Southwest of Nigeria. Research Journal.Vol. 2 No. 1: 24-30.

[8] Okumadewa, F.O. 1999. Livestock Industry as a tool For poverty alleviation. Tropical Journal of Animal Science. 2: 21-30.

[9] Okunlola, J.O and Olofinsawe, A. 2007.Effects of extension activities on Poultry Production in Ondo State, South Western Nigeria. Agricultural Journal, 2: 559-563.

[10] Oyediji, G. O. (2006). Feedmill Management in Nigeria.A Handbook for Animal Scientists, Feedmillers, Agriculture Students and Allied Professionals.University Press Ibadan ISBN 978-074-995-0.PP. x-xiii. 